\title{
Dahili Kliniklerde Çalışan Hekim ve Hemşirelerde Ölüm Kaygısının Belirlenmesi
}

\author{
Şuhule TEPE MEDiN ${ }^{1}$, Sevilay HINTISTAN ${ }^{2}$, Yavuz ÖZORAN ${ }^{3}$
}

\section{öz}

Amaç: Bu çalışma, dahili kliniklerde çalışan hekim ve hemşirelerde ölüm kaygısının belirlenmesi amacıyla yapıımıştır.

Gereç ve Yöntem: Bu çalışma tanımlayıcı tiptedir. Araştırmanın evrenini Ordu Devlet Hastanesi dahili kliniklerde çalışan 51 hekim ve 196 hemşire; örneklemini ise araştırma kabul ölçütlerine uyan 47 hekim ve 139 hemşire olmak üzere toplam 186 kişi oluşturmuştur. Veriler "Kişisel Bilgi Formu" ve "Ölüm Kaygısı Ölçeği" kullanılarak toplanmıştır. Verilerin değerlendirilmesinde yüzdelik, ortalama, minimum ve maksimum değerler, $\mathrm{t}$ testi ve tek yönlü ANOVA testi kullanılmıştır.

Bulgular: : Hekim ve hemşirelerin orta düzeyde ölüm kaygılarının olduğu ancak hemşirelerin ölüm kaygısının hekimlerden anlamlı olarak daha yüksek olduğu belirlenmiştir. Hekimlerin ölüm kaygısını çocuk sayısı, evde birlikte yaşanılan kişiler ve dindarlık düzeyi; hemşirelerin ölüm kaygısını kurumda çalışma pozisyonu, ölümü düşünme sıkıı̆ı, ölümle ilgili düşüncelerini paylaşma ve ölüme ilişkin hizmet içi eğitim alma istatistiksel olarak anlamlı şekilde etkilemiştir.

Sonuç: Hemşirelerin ölüm kaygııının hekimlerden daha yüksek olduğu bulunmuştur. Hekim ve özellikle hemşirelerin ölüm kaygısıyla olumlu baş etmelerini sağlayacak yöntemleri bulmaları konusunda desteklenmesi önerilir.

Anahtar kelimeler: Hekim, hemşire, kaygı, ölüm, ölüm kaygısı

\begin{abstract}
Determination of Death Anxiety in Physicians and Nurses Working in Internal Clinics

Aim: The study was conducted to determine death anxiety in physicians and nurses working in internal clinics.

Material and Methods: This study is of descriptive type. The population of the study consisted of 51 physicians and 196 nurses working in internal clinics of Ordu State Hospital; the sample consisted of a total 186 people including 47 physicians and 139 nurses who meet the study eligibility criteria. The data were collected using "Personal Information Form" and "Death Anxiety Scale". Percentage, mean, minimum and maximum values, $t$ test and one-way ANOVA test were used in the evaluation of the data. Results: It was determined that physicians and nurses had moderate level of death anxiety but the death anxiety of nurses was significantly higher than physicians. While physicians' death anxiety was affected by the number of children, people living together at home and the level of piety, the death anxiety of nurses was statistically significantly affected by their working position in the institution, frequency of thinking about death, sharing their thoughts about death and receiving in-service training related to death.

Conclusion: Nurses' death anxiety was found to be higher than physicians. It is recommended that physicians and especially nurses are encouraged to find methods that will enable them to deal with death anxiety positively.

Keywords: Anxiety, death, death anxiety, nurse, physician
\end{abstract}

${ }^{1}$ Hemşire, Ordu Devlet Hastanesi, Altınordu/Ordu,Türkiye, E-mail: suhuletm@hotmail.com, Tel: 532 223 45 52, ORCID: 0000-0002-1980-1612

2Prof. Dr., Karadeniz Teknik Üniversitesi, Sağlık Bilimleri Fakültesi Hemşirelik Bölümü, İç Hastalıkları Hemşireliği Anabilim Dalı, Trabzon, Türkiye, E-mail: sevilayhindistan@gmail.com, sevilayhindistan@ktu.edu.tr, Tel: 54224808 01, ORCID: 0000-0002-5907-5723

3Prof. Dr., Avrasya Üniversitesi Rektörlüğü, Trabzon, Türkiye, E-mail: yavuz.ozoran@avrasya.edu.tr, Tel: 532 179 86 17, ORCID: 000-0001-9795-5329

Geliş Tarihi: 25 Şubat 2020, Kabul Tarihi: 9 Eylül 2020

* Bu çalışma, Avrasya Üniversitesi Sağlık Bilimleri Enstitüsü Hemşirelik Anabilim Dalı Yüksek Lisans tez çalışmasıdır.

Atıf/Citation: Medin Tepe Ş, Hintistan S, Özoran Y. Dahili Kliniklerde Çalışan Hekim ve Hemşirelerde Ölüm Kaygısının Belirlenmesi. Hacettepe Üniversitesi Hemşirelik Fakültesi Dergisi 2020; 7(3): 262-270. DOI: 10.31125/hunhemsire.834176 


\section{GíRiş}

Doğumun doğallığı kadar ölüm de doğaldır. Ancak doğumdaki doğallık anlayışı, ölümün doğallığında algılanmamaktadır ${ }^{1}$. Ölüm, "bir canlının beyin, solunum ve dolaşım faaliyetlerinin dönüşümsüz olarak durması, tüm organ ve dokularındaki hücrelerin fiziksel ve kimyasal etkinliğini kaybetmesi nedeniyle yaşamın sona ermesidir"2. Ölüm kaygısı ise "kişinin varlığına gerçek ya da hayali bir tehdit algısı ile ortaya çıkan rahatsız edici huzursuzluk ya da korku" olarak tanımlanır ${ }^{3}$. Birçok psikolojik kaygının temelinde yatan ölüm kaygısını göz ardı etmek, insan davranışlarının önemli bir yönünü ihmal etmek anlamına gelir ${ }^{1,4}$.

Teknoloji ve sağlık sisteminin gelişmesi ile birlikte özellikle son dönem hastaları daha iyi ve kaliteli bir bakım için son dönemlerini hastanede geçirmeyi tercih etmektedir ${ }^{5}$. Dahili klinikler olan kardiyoloji, nefroloji ve onkoloji gibi klinikler kronik ve uzun süreli hasta yatışlarının olduğu kliniklerdir6. Bu kliniklerde hekim ve hemşireler kanser, kalp yetmezliği ve son dönem böbrek yetmezliği gibi karmaşık sağlık sorunlarına sahip hastalara bakım vermekte, kayıp, ölüm ve yas süreçleri ile sıklıkla karşılaşmaktadır ${ }^{7}$

Modern tıpla birlikte tedavi ve bakım kalitesi artmış, kronik ve ölümcül hastalıklarla yaşanan süre uzamıştır. Ölümlerin büyük bir bölümü hastanelerde gerçekleşmeye başlamış, ölüm toplum dışına atılan bir olgu haline gelmiştir. Bu durum hekim ve hemşirelerin ölümle daha sık karşılaşmasına ve ölümün duygusal yükünü daha çok hissetmesine yol açmıştır ${ }^{8}$. Uzun süre hastalık ve ölüm olaylarına maruz kalma ölüm kaygısının gelişmesine neden olmaktadır ${ }^{9}$. Ölüm olgusu sadece hasta ve ailesi için değil hekim ve hemşireler için de kaygı verici bir durumdur. Ölümle yüzleşmenin korkunç bir deneyim olduğu belirtilmektedir ${ }^{5}$.

Ölmekte olan hastaya bakım veren hekim ve hemşireler, tedavi ve bakım sürecinde yeterli ve başarılı olamamaktan korkmakta hatta suçluluk duymaktadır. Ölümle karşılaşan hekim ve hemşireler kendi ölüm gerçeği ile yüzleşmekte, duygusal olarak zorlanmakta, kendi nöbetlerinde kayıp yaşamak ve kötü haberi vermek istememektedir ${ }^{8}$. Bu nedenle hasta ve ailesi ile ölüm konusunda konuşmaktan kaçınmakta, tedaviye odaklanarak hasta ve ailesinin duygusal durumuna yeterli önemi vermemekte ve mümkün olduğunca az iletişim kurma yoluna gitmektedirler ${ }^{8,10}$.

Hekimlerin diğer meslek profesyonellerinden daha fazla ölüm kaygısı yaşadıkları ve hatta bu korkularını yenmek için hekim oldukları ileri sürülmektedir ${ }^{9}$. Hekimlerin ölüm kaygısı, tedavi kalitesini olumsuz etkilemesi nedeniyle oldukça önemlidirr ${ }^{11}$. Özkırış ve ark.nın (2011) 304 hekimle yaptığı çalışmada, ölüm kaygısı yüksek saptanan hekim oranı dahili tıp grubunda \%47.1, cerrahi tıp grubunda \%39.2 ve temel tıp/radyoloji grubunda \%65.9 olarak bulunmuş, temel tıp/radyoloji grubunda ölüm kaygı düzeyinin, cerrahi tıp grubuna göre anlamlı olarak yüksek olduğu saptanmıştır. Aynı çalışmada, hekimlerin \%94.4'ü "tıp eğitimi sırasında ve sonrasında ölüm ve ölümcül hastaya yaklaşımla ilgili eğitim gereklidir" ve \%98.8'i “ölüm ve ölümcül hastaya yaklaşımda, hasta-hekim ilişkisinde zorluk yaşanılan durumlarda profesyonel yardım gereklidir" ifadesini kullanmışlardır ${ }^{9}$.
Hasta bakımında söz sahibi olan hemşireler ölüm karşısında kendilerini yorgun, endişeli ve hazırlıksız hissetmektedir. Hemşireler; ölüm ve ölümle ilişkili stres faktörleri nedeniyle kaygı, çaresizlik, öfke ve sıkıntı yaşamakta, hasta ve aile üyeleriyle iletişimde güçlük yaşamaktadır ${ }^{5}$. Ölüm olayına sıkça tanık olma, hastayla en çok vakit geçiren hemşirelerin ölüm kaygılarının artmasına neden olmaktadır ${ }^{12}$. Hemşirelerde ölüm kaygısının artması, ölmek üzere olan hastaya bakım veren hemşirelerin olumsuz tutum sergilemesine, ölümle ilgili konuları hasta ve ailesiyle tartışma konusunda isteksiz olmalarına yol açmaktadır ${ }^{13}$. Ölüme ilişkin korkularının farkında olmayan bir hemşire, hastaya yardım edemeyeceğini düşünerek sorumluluk almaktan korkmakta ve hastadan kaçınıcı bir tutum sergilemektedir ${ }^{14}$. Cooper ve Barnett (2015), yaşam sonu dönemdeki bir hastaya bakım vermenin öğrenci hemşirelerde kaygı oluşturduğunu saptamıştır ${ }^{15}$. Koç ve Sağlam (2008), öğrencilerin \%75.7'sinin son dönemdeki hastanın bakımı için kendilerini yetersiz gördüklerini belirtmiştir ${ }^{16}$. Çevik'in (2010) çalışmasında ise hemşirelerin çoğunluğu (\%83.3) ölmekte olan hastaya bakım vermekte ve bakım verirken sıklıkla keder (\%37.5) yaşamaktadır. Aynı çalışmada, hemşirelerin yarıdan fazlası ölmekte olan hastaya bakım vermek istemediklerini ve çoğunluğu ölüm kavramını hasta ve yakınları ile rahat konuşamadıklarını ifade etmişlerdir ${ }^{17}$.

Hekim ve hemşirelerin ölümü korkutucu algılamaları hastalara verilen tedavi ve bakım kalitesini olumsuz etkilemektedir. Oysaki, ölümü yaklaşan hastalar için tedavi ve bakım standartlarının belirlenmesi ve takip edilmesi kaliteyi arttırmada önemli katkılar sağlayacaktır ${ }^{18}$. Kaliteli tedavi ve bakımın sunulmasında yaşam, ölüm, kayıp ve yas süreçlerinde bireysel duyguların, davranış ve tutumların farkında olunması, ölümü yaklaşan hasta ve ailesi ile etkin iletişim kurularak destek sağlanması önemlidir. Bu nedenle hekim ve hemşirelerin ölüme ilişkin duygularını anlatabilmesi, ölüm süreci ile ilgili bilgisinin olması, ölmekte olan hastanın fiziksel ve psikososyal özellikleri ile hasta ve ailesinin gereksinimlerine farkındalık oluşturması ve desteklemesi gereklidir ${ }^{12}$. Beklenen ölüm karşısında aile tepkilerinin anlaşılmasında, ölüm yaklaşırken ve yas sürecinde ailelere yardım etmeye hazır olunmasında hekim ve hemşirelerin yaşam ve ölümle ilgili sorunları ile yüzleşmesi, ölüme karşı kendi duygularının farkında olması önemlidir ${ }^{19}$.

Bu çalışma, dahili kliniklerde çalışan hekim ve hemşirelerde ölüm kaygısını belirlemek amacı ile yapılmıştır. Hekim ve hemşirelerdeki ölüm kaygısının yol açacağı tedavi ve bakım sürecindeki problemleri engellemek adına bu araştırmanın yararlı olacağı ve özellikle dahili tıp ve hemşirelik alanında yol gösterici olabileceği düşünülmektedir. Ayrıca, bu çalışma ile ülkemizde çalışan hekim ve hemşirelerdeki ölüm kaygısını ve ölüm kaygısını hangi faktörlerin etkilediğini ortaya koyabilecek ve ortaya çıkan sonuçlar, sağlık kurumlarının ve farklı araştırma merkezlerinin hekim ve hemşirelerle ilgili ölüm kaygısı çalışmalarına ışık tutabilecektir.

\section{Araştırmanın Amacı}


Bu çalışma, dahili kliniklerde çalışan hekim ve hemşirelerde ölüm kaygısının belirlenmesi amacıyla gerçekleştirilmiştir.

\section{Araştırmanın Soruları}

1. Araştırmaya katılan hekim ve hemşirelerin ölüm kaygı puanları nasıldır?

2. Araştırmaya katılan hekim ve hemşirelerin tanıtıcı özelliklerine göre ölüm kaygı puanları nasıldır?

3. Araştırmaya katılan hekim ve hemşirelerin ölüme ilişkin özelliklerine göre ölüm kaygı puanları nasıldır?

\section{GEREÇ ve YÖNTEM}

\section{Araştırmanın Türü}

Bu araştırma, tanımlayıcı tipte bir araştırmadır.

\section{Araştırma Evren ve Örneklemi}

Araştırmanın evrenini Ordu Devlet Hastanesi dahili kliniklerde (dahiliye, göğüs hastalıkları, enfeksiyon hastalıkları, onkoloji, nefroloji, cildiye, nöroloji, kardiyoloji) çalışmakta olan tüm hekim $(\mathrm{N}=51)$ ve hemşireler $(\mathrm{N}=196)$ oluşturmaktadır. Ancak geçici görevde olma (21 hemşire), raporlu/izinli olma (22 hemşire) ve araştırmaya katılmaya kabul etmeme (4 hekim; 14 hemşire) nedenleri ile çalışmaya 186 kişi (47 hekim ve 139 hemşire) katılmıştır. Araştırmaya katılanların \%25.2'sini hekimler, \%74.8'ini hemşireler oluşturmuştur. Çalışmaya katılım oranı hekimlerde \%92.1, hemşirelerde \%70.9'dur.

\section{Veri Toplama Araçları}

Veriler, "Kişisel Bilgi Formu” ve "Ölüm Kaygısı Ölçeği (ÖKÖ)" kullanılarak toplanmıştır.

Kişisel Bilgi Formu: íki bölümden oluşan bu form, araştırmacı tarafından literatür taranarak (1-19) ve anlaşıırlık ve kapsam geçerliği yönünden İç Hastalıkları Hemşireliği Anabilim Dalı’ndan üç öğretim üyesinin uzman görüşleri alınarak hazırlanmıştır. Birinci bölümde, hekim ve hemşirelerin tanıtıcı özelliklerini (yaş, cinsiyet, medeni durum, eğitim düzeyi, çocuk sayısı, evde birlikte yaşanılan kişiler, kurumda görev pozisyonu, çalışma süresi) belirlemeye yönelik sekiz soru yer almıştır. İkinci bölümde ise hekim ve hemşirelerin ölüme ilişkin özelliklerini (çalışılan klinikte ölümle karşılaşıp karşılaşmadığı, ölümü düşünme sıklığı, daha önce kayıp/yas yaşama, ölümle ilgili düşüncelerini paylaşma, dindarlık düzeyini değerlendirme, ölüme ilişkin hizmet içi eğitim alma) belirlemeye yönelik altı soru yer almıştır. Kişisel Bilgi Formu toplam 14 sorudan oluşmuştur.

Ölüm Kaygısı Ölçeği (ÖKÖ): ÖKÖ, Templer (1970) tarafından geliştirilmiştir ${ }^{20}$. ÖKÖ, 15 maddelik Evet/Hayır şeklinde yanıtlanan bir ölçektir. Ölçekteki ilk 9 maddeye verilen her bir "evet" yanıtı için "1", "hayır" yanıtı için " 0 ", diğer 6 maddeye verilen her bir "hayır" yanıtı için "1", "evet" yanıtı için " 0 " puan alınmaktadır. Ölçekten alınacak en düşük puan " 0 " ve en yüksek puan "15" dir. Toplam puan, ölüm kaygı puanını gösterir ve puan arttıkça ölüm kaygısı düzeyinin arttığı şeklinde yorumlanır. ÖKÖ’nün Türkçe uyarlama, güvenirlik ve geçerlilik testleri Akça ve Köse (2008) tarafından yapılmıştır ${ }^{21}$. Ölçeğin test-tekrar test güvenirliği .79 ve Kuder-Richardson formülü ile hesaplanan güvenirlik katsayısı ise .75 olarak bulunmuştur. Bu bulgular Templer'in (1970) orijinal çalışmasında bulunan .83 ve .76'lara benzerdir. Bu çalışma için ÖKÖ’nün alfa iç tutarlılık katsayısı .75 olarak bulundu. Ölçek kullanımı için izin alınmıştır.

\section{Veri Toplama Araçlarının Uygulanması}

Kişisel Bilgi Formu ve ÖKÖ, Mart - Haziran 2017 tarihleri arasında hekim ve hemşirelere araştırmacı tarafından yüz yüze görüşme tekniği kullanılarak uygulanmıştır. Kişisel Bilgi Formu ve ÖKÖ, hekim ve hemşirelerin çalıştığı klinikte hekim ve hemşire odasında her iki tarafın da uygun bulduğu bir zaman içerisinde doldurulmuştur. Formlarda hekim ve hemşirelerin isimlerine yer verilmemiş ve formların doldurulması yaklaşık 15 dakika sürmüştür.

\section{Verilerin Analizi}

Araştırmadan elde edilen verilerin değerlendirilmesinde, verilerin kodlanması ve istatistiksel analizler için SPSS v25 (Statistical Package for Social Sciences) programı (IBM Inc., Chicago, IL, USA) kullanılmıştır. Verilerin normal dağılıma sahip olma durumu Kolmogorov-Smirnov testi ile grup varyanslarının homojenlik kontrolü Levene testi ile yapılmıştır. Sürekli değişkenler ortalama, standart sapma (minimum-maksimum değerler) ve kategorik değişkenler sayı (yüzde) olarak verilmiştir. Sürekli değişkenler arasındaki farklılığın değerlendirilmesinde, iki grup ortalaması student t testi ile ikiden fazla grup ortalaması tek-yönlü varyans analizi (One-way ANOVA) ile değerlendirilmiştir. Varyans analizi sonrası gerekli olması durumunda farklı ortalamalar Tukey çoklu karşılaştırma testi ile belirlenmiştir. Sonuçlar \%95 güven aralığında anlamlılık $\mathrm{p}<0.05$ düzeyinde değerlendirilmiştir.

\section{Araştırmanın Etik Boyutu}

Araştırmanın yapılabilmesi için Sağlık Bilimleri Üniversitesi Trabzon Kanuni Eğitim Araştırma Hastanesi Bilimsel Araştırmalar Kurulu'ndan (No:23618724) etik kurul izni alınmıştır. Ayrıca, Ordu ili Kamu Hastaneler Birliği Genel Sekreterliği'ne başvuru yapılarak Ordu Devlet Hastanesi Başhekimliği'nden araştırmanın amaç ve kapsamını içeren bilgi formu sunularak yazılı kurum izni alınmıştır. Yine hekim ve hemşirelerden (araştırmaya katılmaya isteklilik, gönüllülük ilkesine özen gösterilerek) sözel onamları alınmıştır. Araştırmada insan olgusunun kullanımında bireysel hakların korunması gerektiğinden Bilgilendirilmiş Onam koşulu yerine getirilmiştir. Araştırma ve yayın sürecinde Helsinki Deklerasyonu Prensiplerine, araştırma ve yayın etiğine uygun hareket edilmiştir.

\section{Araştırmanın Sınırlılıkları}

Araştırma Ordu ili devlet hastanesi ile sınırlıdır. Evrenin tamamına ulaşılması hedeflenmiş, ancak hekimlerde evrenin \%92.1'ine ( $\mathrm{N}=47)$, hemşirelerde ise \%70.9'una ( $\mathrm{N}=139)$ ulaşılmıştır. Araştırmadan elde edilen veriler, araştırmaya katılmayı kabul eden hekim ve hemşirelerin bildirimine dayalıdır ve elde edilen sonuçlar örneklem dışına genellenemez. Araştırmadan elde edilen sonuçlar kullanılan ölçüm araçlarının güvenilirlik ve geçerlilik boyutları ve kullanılan istatistiksel yöntemler ile sınırlıdır. Ayrıca, veri toplama araçlarının hekim ve hemşirelerin çalışma saatleri içerisinde uygulanması ve nöbet sistemi ile çalışanlara ulaşmada güçlük yaşanması bu araştırmanın bir diğer sınırlılığıdır. 


\section{BULGULAR}

Hekim ve Hemşirelerin ÖKÖ Puan Ortalamalarına Ait Bulgular

Hekimlerin ÖKÖ puan ortalaması $7.21 \pm 2.60$, hemşirelerin ÖKÖ puan ortalaması $8.42 \pm 2.89$ 'dur. Hemşirelerin ÖKÖ puan ortalamaları, hekimlerden anlamlı düzeyde daha yüksektir $(p<0.05)$ (Tablo 1$)$.

Tablo 1. Hekim ve Hemşirelerin ÖKÖ Puan Ortalamaları (n=186)

\begin{tabular}{|l|l|l|l|}
\hline & $\mathbf{n}$ & $\begin{array}{l}\text { ÖKÖ } \\
\mathbf{X} \pm S S\end{array}$ & Med (Min-Maks) \\
\hline Hekim & 47 & $7.21 \pm 2.60$ & $7(2-12)$ \\
\hline Hemşire & 139 & $8.42 \pm 2.89$ & $8(2-15)$ \\
\hline Toplam & 186 & $8.11 \pm 2.87$ & $8(2-15)$ \\
\hline p=0.012 (t=-2.539) & & \\
\hline
\end{tabular}

Hekim ve Hemşirelerin Tanıtıcı Özelliklerine Göre ÖKö Puan Ortalamalarına Ait Bulgular

Araştırmaya katılan hekimlerin $\% 80.9^{\prime} u$, hemşirelerin \%66.9'u 36-45 yaş arasında; hekimlerin \%63.8'i erkek, hemşirelerin \%92.8'i kadın; hekimlerin \%87.2'si, hemşirelerin \%84.2'si evli; hekimlerin \%100'ü uzman ve hemşirelerin \%43.9'u ön lisans mezunudur. Hekimlerin $\% 76.6$ 'sı hemşirelerin \%82'si 1-3 çocuğa sahip; hekimlerin $\% 68.1^{\prime} i$, hemşirelerin \%69.8'i eş ve çocukları ile birlikte yaşamakta; hekimlerin \%89.4'ü kurumda uzman hekim olarak, hemşirelerin \%89.9'u klinik hemşiresi olarak çalışmaktadır. Hekimlerin \%42.6'sı 11-15 yıl, hemşirelerin $\% 62.6$ 'sı 16 yıl ve üzeri süredir çalışmaktadır.

Hekimlerin çocuk sayısı ile ÖKÖ puan ortalamaları arasında gruplar arası anlamlı farklılık vardır ve bu farklııı 1-3 ve 4-6 çocuğu olan hekimlerden kaynaklanmaktadır $(p<0.05)$. Yine hekimlerin evde birlikte yaşadığı kişiler ile ÖKÖ puan ortalamaları arasında gruplar arası anlamlı farklılık saptanmış ve bu farklılığın "eş ve çocuklar" ve "anne-baba" ile yaşayan hekimlerle, "anne-baba" ve "geniş aile" ile yaşayan hekimler arasında olduğu belirlenmiştir $(p<0.05)$. Hemşirelerin kurumda çalışma pozisyonlarına göre ÖKÖ puan ortalamaları arasında gruplar arası anlamlı farklılık saptanmış ve klinik sorumlu hemşirelerin ÖKÖ puan ortalamaları klinik hemşirelerden daha yüksek bulunmuştur $(p<0.05)$ (Tablo 2).

Hekimlerin yaşı, cinsiyeti, medeni durumu, kurumda görev pozisyonu ve çalışma süresi; hemşirelerin yaşı, cinsiyeti, medeni durumu, eğitim düzeyi, çocuk sayısı, evde birlikte yaşadığı kişiler ve çalışma süresi ÖKÖ puan ortalamalarını anlamlı olarak etkilememiştir ( $p>0.05$ ) (Tablo 2).

Araştırmaya katılan hekimlerin \%87.2'si, hemşirelerin \%91.4'ü çalıştığı klinikte ölümle karşılaşmakta; hekimlerin $\% 63.8$ 'i, hemşirelerin $\% 59$ 'u ölümü "ara ara" düşünmektedir. Hekimlerin \%78.7'si, hemşirelerin \%84.2'si daha önce kayıp/yas yaşamış; hekimlerin \%63.8'i, hemşirelerin \%66.9'u ölümle ilgili düşüncelerini paylaşmakta; hekimlerin $\% 61.7$ 'si, hemşirelerin $\% 79.1$ 'i dindarlık düzeyini "orta" olarak değerlendirmektedir.
Hekimlerin tamamı, hemşirelerin \%91.4'ü ölüme ilişkin hizmet içi eğitim almamıştır (Tablo 3).

Hekimlerin dindarlık düzeyini değerlendirmesi ile ÖKÖ puan ortalamaları arasında gruplar arası anlamlı farklılık saptanmış ve bu farklılık "dindarlık düzeyini yüksek değerlendiren" hekimlerle "dindarlık düzeyini düşük değerlendiren" hekimlerden kaynaklanmıştır ( $p<0.05)$.

Hemşirelerin ÖKÖ puan ortalamaları ölümü düşünme sıklığına göre gruplar arası anlamlı farklılık göstermiş ve bu farklılığın "ölümü sık sık düşünen" hemşirelerle "ölümü hiç düşünmeyen" hemşirelerden kaynaklandığı belirlenmiştir $(p<0.05)$. Yine ölümle ilgili düşüncelerini paylaşan hemşirelerin ÖKÖ puan ortalamaları ölümle ilgili düşüncelerini paylaşmayan hemşirelerin puan ortalamalarından anlamlı olarak daha yüksek bulunmuştur $(p<0.05)$. Ayrıca, hemşirelerin ölüme ilişkin hizmet içi eğitim almaları ile ÖKÖ puan ortalamaları arasında anlamlı farklııı saptanmış ve ölüme ilişkin hizmet içi eğitim almayan hemşirelerin ÖKÖ puan ortalamaları eğitim alan hemşirelerin ÖKÖ puan ortalamalarından daha yüksek bulunmuştur $(p<0.05)$ (Tablo 3$)$.

Hekimlerin "çalışılan klinikte ölümle karşılaşma, ölümü düşünme sıklığı, daha önce kayıp/yas yaşama, ölümle ilgili düşüncelerini paylaşma ve ölüme ilişkin hizmet içi eğitim alma durumları"; hemşirelerin "çalışılan klinikte ölümle karşılaşma, daha önce kayıp/yas yaşama ve dindarlık düzeyini değerlendirme durumları" ÖKÖ puan ortalamalarını anlamlı olarak etkilememiştir $(p>0.05)$

(Tablo 3). 
Tablo 2. Hekim ve Hemşirelerin Tanıtıcı Özelliklerine Göre ÖKÖ Puan Ortalamaları ( $n=186)$

\begin{tabular}{|c|c|c|c|c|c|c|}
\hline \multirow{2}{*}{$\begin{array}{l}\text { Tanıtıcı } \\
\text { Özellikler }\end{array}$} & \multicolumn{3}{|c|}{ Hekim (n=47) } & \multicolumn{3}{|c|}{ Hemşire (n=139) } \\
\hline & n (\%) & 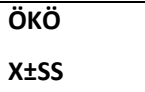 & $\mathbf{p}$ & n (\%) & 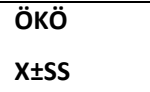 & $\mathbf{p}$ \\
\hline \multicolumn{7}{|l|}{ Yaş } \\
\hline $18-35$ & $1(2.1)$ & $9.00^{\#}$ & 0.091 & $28(20.2)$ & $8.17 \pm 3.12$ & 0.275 \\
\hline $36-45$ & 38 (80.9) & $7.47 \pm 2.63$ & $\mathrm{t}=1.729$ & 93 (66.9) & $8.30 \pm 2.76$ & $F=1.305$ \\
\hline $46-61$ & $8(17.0)$ & $5.75 \pm 2.12$ & & $18(12.9)$ & $9.44 \pm 3.14$ & \\
\hline \multicolumn{7}{|l|}{ Cinsiyet } \\
\hline Kadın & $17(36.2)$ & $7.64 \pm 2.73$ & 0.395 & $129(92.8)$ & $8.51 \pm 2.92$ & 0.166 \\
\hline Erkek & $30(63.8)$ & $6.96 \pm 2.53$ & $\mathrm{t}=0.858$ & $10(7.2)$ & $7.20 \pm 2.34$ & $t=1.391$ \\
\hline \multicolumn{7}{|l|}{ Medeni durum } \\
\hline Evli & $41(87.2)$ & $7.29 \pm 2.36$ & 0.730 & $117(84.2)$ & $8.35 \pm 2.72$ & 0.541 \\
\hline Bekar & $6(12.8)$ & $6.66 \pm 4.13$ & $\mathrm{t}=0.363$ & $22(15.8)$ & $8.77 \pm 3.76$ & $t=-0.613$ \\
\hline \multicolumn{7}{|l|}{ Eğitim düzeyi } \\
\hline Lise & - & - & - & $9(6.5)$ & $8.11 \pm 3.18$ & 0.502 \\
\hline Ön lisans & - & - & & 61 (43.9) & $8.85 \pm 2.46$ & $F=0.790$ \\
\hline Lisans & - & - & & $59(42.4)$ & $8.10 \pm 3.16$ & \\
\hline Lisanüstü/ Uzman & $47(100.0)$ & $7.21 \pm 2.60$ & & $10(7.2)$ & $8.00 \pm 3.52$ & \\
\hline \multicolumn{7}{|l|}{ Çocuk sayısı } \\
\hline Yok & $8(17.0)$ & $6.37 \pm 3.54^{\mathrm{ab}}$ & 0.019 & $19(13.7)$ & $8.73 \pm 3.81$ & 0.854 \\
\hline $1-3$ çocuk & $36(76.6)$ & $7.69 \pm 2.16^{\mathrm{a}}$ & $F=4.371$ & $114(82.0)$ & $8.36 \pm 2.76$ & $F=0.158$ \\
\hline Yalnız & $5(10.6)$ & $7.60 \pm 3.84^{\mathrm{ab}}$ & 0.025 & $12(8.6)$ & $7.16 \pm 3.56$ & 0.234 \\
\hline Eş ile & $5(10.6)$ & $6.60 \pm 2.40^{\mathrm{ab}}$ & $F=3.112$ & $12(8.6)$ & $8.50 \pm 2.46$ & $\mathrm{~F}=1.410$ \\
\hline Eş ve çocuklar & $32(68.1)$ & $7.37 \pm 2.22^{\mathrm{a}}$ & & $97(69.8)$ & $8.45 \pm 2.79$ & \\
\hline Anne baba & $2(4.3)$ & $2.00 \pm 0.00^{b}$ & & $8(5.8)$ & $10.25 \pm 3.61$ & \\
\hline Geniş aile & $3(6.4)$ & $9.33 \pm 1.52^{\mathrm{a}}$ & & $10(7.2)$ & $8.10 \pm 2.68$ & \\
\hline \multicolumn{7}{|c|}{ Kurumda görev pozisyonu } \\
\hline Uzman hekim & $42(89.4)$ & $7.09 \pm 2.66$ & 0.376 & - & - & 0.040 \\
\hline Klinik sorumlu hekim & $5(10.6)$ & $8.20 \pm 1.92$ & $t=-0.895$ & - & - & \\
\hline Klinik hemşire & - & - & & 125 (89.9) & $8.25 \pm 2.85$ & \\
\hline Klinik sorumlu hemşire & - & - & & $14(10.1)$ & $9.92 \pm 2.92$ & \\
\hline \multicolumn{7}{|l|}{ Çalışma süresi } \\
\hline 1 yıldan az & - & - & 0.471 & $2(1.4)$ & $9.00 \pm 0.00$ & 0.339 \\
\hline $1-5$ yıl & $1(2.1)$ & $5.000^{\#}$ & $F=0.767$ & $10(7.2)$ & $6.80 \pm 2.97$ & $F=1.144$ \\
\hline 6-10 yıl & $9(19.1)$ & $8.22 \pm 1.48$ & & $15(10.8)$ & $8.80 \pm 2.70$ & \\
\hline 11-15 yıl & $20(42.6)$ & $7.10 \pm 3.21$ & & $25(18.0)$ & $8.00 \pm 2.61$ & \\
\hline 16 yıl ve üstü & $17(36.2)$ & $6.94 \pm 2.27$ & & $87(62.6)$ & $8.65 \pm 3.00$ & \\
\hline
\end{tabular}


Tablo 3. Hekim ve Hemşirelerin Ölüme ilişkin Özelliklerine Göre ÖKÖ Puan Ortalamaları ( $n=186)$

\begin{tabular}{|c|c|c|c|c|c|c|}
\hline \multirow[t]{2}{*}{ Ölüme ilişkin Özellikler } & \multicolumn{3}{|c|}{ Hekim $(n=47)$} & \multicolumn{3}{|c|}{ Hemşire $(n=139)$} \\
\hline & n (\%) & $\begin{array}{l}\text { ÖKÖ } \\
\mathrm{X} \pm S S\end{array}$ & p & n (\%) & $\begin{array}{l}\text { ÖKÖ } \\
\mathrm{X} \pm \text { SS }\end{array}$ & p \\
\hline \multicolumn{7}{|c|}{ Çalışılan klinikte ölümle karşılaşma } \\
\hline Evet & $41(87.2)$ & $7.09 \pm 2.64$ & 0.434 & $127(91.4)$ & $8.43 \pm 2.91$ & 0.910 \\
\hline Hayır & $6(12.8)$ & $8.00 \pm 2.36$ & $t=0.790$ & $12(8.6)$ & $8.33 \pm 2.83$ & $(t=0.114)$ \\
\hline \multicolumn{7}{|l|}{ Ölümü düşünme sıklığı } \\
\hline Sık sık & $10(21.3)$ & $6.80 \pm 2.86$ & 0.220 & $45(32.4)$ & $9.11 \pm 3.08^{\mathrm{a}}$ & 0.048 \\
\hline Ara ara & $30(63.8)$ & $7.66 \pm 2.63$ & $F=1.568$ & $82(59.0)$ & $8.26 \pm 2.59^{\mathrm{ab}}$ & $F=3.095$ \\
\hline Hiç düşünmem & $7(14.9)$ & $5.85 \pm 1.67$ & & $12(8.6)$ & $6.91 \pm 3.65^{b}$ & \\
\hline \multicolumn{7}{|c|}{ Daha önce kayıp / yas yaşama } \\
\hline Evet & $37(78.7)$ & $7.13 \pm 2.60$ & 0.699 & $117(84.2)$ & $8.54 \pm 2.95$ & 0.252 \\
\hline Hayır & $10(21.3)$ & $7.50 \pm 2.71$ & $t=0.390$ & $22(15.8)$ & $7.77 \pm 2.52$ & $t=0.151$ \\
\hline \multicolumn{7}{|c|}{ Ölümle ilgili düşüncelerini paylaşma } \\
\hline Evet & $30(63.8)$ & $7.56 \pm 2.62$ & 0.220 & $93(66.9)$ & $8.91 \pm 2.88$ & 0.004 \\
\hline Hayır & $17(36.2)$ & $6.58 \pm 2.52$ & $t=1.245$ & $46(33.1)$ & $7.43 \pm 2.68$ & $t=2.906$ \\
\hline \multicolumn{7}{|c|}{ Dindarlık düzeyini değerlendirme } \\
\hline Yüksek & $7(14.9)$ & $5.00 \pm 2.58^{b}$ & 0.030 & $11(7.9)$ & $8.90 \pm 3.98$ & 0.423 \\
\hline Orta & 29(61.7) & $7.27 \pm 2.56^{\mathrm{ab}}$ & $F=3.278$ & $110(79.1)$ & $8.53 \pm 2.73$ & $F=0.940$ \\
\hline Düşük & $6(12.8)$ & $9.16 \pm 1.60^{\mathrm{a}}$ & & $14(10.1)$ & $7.64 \pm 3.20$ & \\
\hline Dindar değil & $5(10.6)$ & $7.60 \pm 2.074^{\mathrm{ab}}$ & & $4(2.9)$ & $6.75 \pm 2.98$ & \\
\hline \multicolumn{7}{|c|}{ Ölüme ilişkin hizmet içi eğitim alma } \\
\hline Evet & - & - & - & $12(8.6)$ & $5.91 \pm 3.05$ & 0.001 \\
\hline Hayır & $47(100.0)$ & $7.21 \pm 2.60$ & & $127(91.4)$ & $8.66 \pm 2.78$ & $t=3.241$ \\
\hline
\end{tabular}

ÖKÖ=Ölüm kaygısı ölçeği, \# istatistik analizlerde dikkate alınmamıştır.

Ortak harfi olmayan ortalamalar arasındaki farklılık istatistiksel olarak önemlidir $(p<0.05)$ 


\section{TARTIŞMA}

Bu çalışmada, dahili kliniklerde çalışan hekim ve hemşirelerin orta düzeyde ölüm kaygısı yaşadıkları ancak hemşirelerin hekimlerden daha yüksek ölüm kaygısına sahip oldukları belirlenmiştir. Çalışmamıza paralel Dönmez $(2012)^{22}$ ile Şahin ve ark. $(2016)^{23}$ hemşirelerin orta düzeyde ölüm kaygısı yaşadıklarını; Özkırış ve ark. (2011) ise ölümcül hasta ve ölümle sık karşılaşan hekimlerde ölüm kaygısının daha düşük olduğunu bulmuşlardır ${ }^{9}$. Yine Hamama-Raz ve ark. da (2000) onkoloji, iç hastalıkları, cerrahi, psikiyatri ve pediatri ünitelerinde çalışan uzman hekimlerle yaptıkları çalışmada, meslekte daha uzun süre çalışan tecrübeli hekimlerde kaygı seviyesini daha düşük saptamışlardır ${ }^{24}$. Hemşirelerin çalışma ortamında ölümcül hastaya bakım verirken anksiyete yaşadığı, keder ve başarısızlık algısı deneyimlediği belirtilmektedir ${ }^{5}$.

Bu çalışmada, hemşirelerin hekimlerden daha yüksek ölüm kaygısına sahip olmalarının nedeni olarak, hemşirelerin hastaların gittikçe kötüleşen durumlarına daha fazla tanıklık ediyor olmaları ile hekimlerin ölümü hemşirelerden daha gerçekçi kabullenişlerinin olabileceği düşünülmüştür.

Çalışmamızda, çocuk sayısı hekimlerin ölüm kaygısını anlamlı olarak etkilemiş ve 1-3 çocuğu olan hekimlerin ÖKÖ puan ortalaması daha yüksek bulunmuştur.

Işık çalışmasında, çocuk sahibi olmanın ölüm korkusu ve ölümden kaçınma puanlarını etkilediğini ve çocuk sahibi olmanın bireyin aile duygusal paylaşımlarını arttırdığını ve bu nedenle daha fazla ölüm korkusu yaşadığını ve aynı zamanda ölüm olayı ile başa çıkmada daha başarılı olduğunu ifade etmiştir ${ }^{14}$.

Çalışma kapsamındaki hekimlerin ölüm kaygısı, evde birlikte yaşadıkları kişilere göre anlamlı farklııı göstermiş ve geniş ailede yaşayan hekimlerin ölüm kaygısı en yüksek bulunmuştur. Bu durum, hekimlerin sağlıkla ilgili konularda kendilerini ailelerinden daha fazla sorumlu hissetmelerinden ve aile üyelerinin ölümlerine tanıklık edebileceklerini düşünmelerinden kaynaklanmış olabilir. Madnawat ve Kachhawa da (2007) ailesiyle birlikte yaşayanların, yalnız yaşayanlardan daha fazla ölüm kaygısı yaşadıklarını belirtmiştir ${ }^{25}$.

Çalışmamızda, klinik sorumlusu olarak çalışmak hemşirelerin ölüm kaygısını arttırmıştır. Bu durum, klinik sorumlu hemşirelerinin hasta/hasta yakını ve kuruma karşı kendilerini daha sorumlu hissetmeleri ve ölüm olayında daha fazla kritik sorumluluk alma zorunlulukları ile açıklanabilir. Özkırış ve ark. (2011) ise mesleki unvanlarla ÖKÖ puan ortalaması arasında anlamlı farklılık saptamamıştır ${ }^{9}$.

Çalışmaya katılan hekimlerin dindarlık düzeyi ölüm kaygısını etkilemiştir. Dindarlık düzeyini belirleyen Tanrı'ya sığınmanın ölümü kabullenmede ve ölüm kaygısını yenmede önemli olduğu, inananların ümit kapılarını açık tuttuğu, endişeyi azalttığı, vicdan azabı ve korkuları yatıştırdığı belirtilmektedir'. Dindarlık düzeyini "düşük" değerlendiren hekimlerin ölüm kaygısı en yüksek bulunmuştur. Ayten, dindarlık düzeyini "zayıf" değerlendirenlerde ölüm kaygısını en yüksek bulmuş, ancak istatistiksel anlamlılık saptamamıştır. Aynı çalışmada dini öğretilerin, dindarlığın ve alınan eğitimin niteliğinin ölüm kaygısında etkili olduğu belirtilmiştir ${ }^{26}$.

Çalışmamızda, ölümü "sık sık düşünen" hemşirelerin ölüm kaygısı, ölümü "ara ara düşünen" hemşirelerden yüksektir. Erdoğdu ve Özkan (2007), ölümü çok sık düşünenlerin ÖKÖ puan ortalamasını en yüksek, ölümü hiç düşünmeyenlerin ÖKÖ puan ortalamasını en düşük bulmuş ve bu durumu "ölümü çok hatırlamak ölüm kaygısını arttırmaktadır" şeklinde yorumlamıştır ${ }^{27}$. Çalışmamıza benzer şekilde Önsöz de (2013), kendi ölümünü çok sık düşünenlerin ölüm kaygısı daha yüksek bulunmuş ve hemşirelerin ölüm empatisi yaptığı şeklinde yorumlanmıştır ${ }^{28}$. Şahin ve ark. (2016) ise hemşirelerin kendi ölümünü "ara sıra" düşünen hemşirelerin ölüm kaygısını, "sık sık" ve "nadiren" düşünenlere göre anlamlı olarak daha yüksek bulmuştur ${ }^{23}$. $\mathrm{Bu}$ çalışmada, ölümle ilgili düşüncelerini paylaşan hemşirelerin ölüm kaygısı, düşüncelerini paylaşmayan hemşirelerden daha yüksektir. Bu durum, ölümle ilgili düşüncelerini paylaşmanın hemşireler için daha önce deneyimlenen ve etkili olduğunu gördükleri bir baş etme yöntemi olarak değerlendirmelerinden kaynaklanabilir. Ayrıca, hemşirelerin ölüm kaygısının hekimlerden daha fazla olması, ölümle ilgili düşüncelerini daha fazla paylaşmalarına da neden olabilir. Çevik (2010) çalışmasında, ölüm olayıyla karşılaşan hemşirelerin baş etme yöntemi olarak "ölümün doğal olduğunu düşünme, dua etme ve arkadaşları ile konuşma" yöntemlerini kullandıklarını belirlemiştir ${ }^{17}$. Yine hemşirelerin kendi ölüm kaygılarının farkında olmalarının ölümü daha rahat konuşmalarına yardımcı olabildiği belirtilmektedir ${ }^{13}$.

Çalışmamızda ölüme ilişkin hizmet içi eğitim almayan hemşirelerin ölüm kaygısı, eğitim alanlardan daha yüksek bulunmuştur. İnci ve Öz (2009), ölüm eğitimi alan hemşirelerin ölüm kaygısını eğitim sonrasında daha düşük bulmuştur ${ }^{29}$. Kurz ve Hayes (2006) hemşirelere uyguladıkları planlı bir eğitim programı sonucunda, hemşirelerin ölüme karşı tutumlarının olumlu yönde değiştiğini ve yaşadıkları ölüm kaygısında azalma olduğunu30; Dadfar ve ark. (2016), ölüm eğitimi verilen hemşirelerin ölüm kaygısında azalma olduğunu ${ }^{18}$; McClatchey ve King de (2015) ölüm eğitimi alan grupta ölüm kaygısının azaldığını belirtmişlerdir ${ }^{31}$. Yine Lewis ve ark. (2016), yaşam sonu bakım ile ilgili verdikleri simülatif eğitim sonrası hemşirelerin ölüm tutumlarında olumlu etki olduğunu gözlemlemiştir ${ }^{32}$. Ölüme ilişkin verilen hizmet içi eğitimlerin hemşirelerin ölüme bakışlarını olumlu etkilediği ve kaygı düzeylerini azalttığı düşünülmüştür.

\section{SONUÇ ve ÖNERILER}

Çalışmamızda hekim ve hemşirelerin orta düzeyde ölüm kaygısına sahip oldukları ancak hemşirelerin ölüm kaygısının hekimlerden daha yüksek olduğu saptanmıştır. Hekim ve hemşirelerin ölüme ilişkin duygularının farkında olmalarını, bu duygularını ifade edebilmelerini ve ölüme ilişkin olumlu tutum geliştirmelerini destekleyecek eğitim programlarının mesleki eğitim sürecinde, kurum oryantasyon aşamasında ve hizmet içi eğitim programlarında verilmesi önerilir. Ayrıca, hekim ve hemşirelere danışmanlık hizmetlerinin verilmesi ve ölüm kaygı düzeylerinin belirli aralıklarla değerlendirilmesi önemlidir. Çalışma sonuçlarının hekim ve 
hemşirelerin ölüm kaygısını ve bunu etkileyen faktörlere ilişkin farkındalığı artırabileceği ve yapılacak çalışmalarda bu konunun daha fazla incelenmesinin yeni öneriler geliştirilmesinde yararlı olabileceği düşünülmektedir.

Etik Kurul Onayı: Sağlık Bilimleri Üniversitesi Trabzon Kanuni Eğitim Araştırma Hastanesi Bilimsel Araştırmalar Kurulu'ndan (No:23618724) etik kurul izni alınmıştır.

Çıkar Çatışması: Bildirilmemiştir.

Finansal Destek: Yoktur.

Katılımcı Onamı: Hekim ve hemşirelerden bilgilendirilmiş onam alınmıştır.

Yazar katkıları:

Araştırma dizaynı: ŞTM, SH, YÖ

Veri toplama: ŞTM, SH

Veri Analizi: STM, SH, YÖ

Makale yazımı: ŞTM, SH, YÖ

Teşekkür

Yazarlar araştırmaya katılmayı kabul eden tüm hekim ve hemşirelere teşekkürlerini sunar.

Ethics Committee Approval: Approval was obtained from the Scientific Research Board of Health Sciences University Trabzon Kanuni Training and Research Hospital (Number: 23618724).

Confict of Interest: Not reported.

Funding: None.

Author contributions:

Study design: ŞTM, SH, YÖ

Data collection: ŞTM, SH

Data analysis: ŞTM, SH, YÖ

Drafting manuscript: ŞTM, SH, YÖ

Acknowledgement:

We would like to thank all physicians and nurses who approved to participate to the study.

\section{KAYNAKLAR}

1. Çınar M. Tanrı'ya bağlanma tarzı ve ölüm kaygısı ilişkisi üzerine bir araştırma. ILTED. 2016;1(45):313-338.

2. Softa HK, Uçukoğlu H, Karaahmetoğlu GU, Esen D. Yaşılırda ölüm kaygısı düzeyini etkileyen bazı faktörlerin incelenmesi. Yaşlı Sorunları Araştırma Dergisi. 2011;(1-2):67-79.

3. Boyd MA. Psychiatric Nursing Contemporary Practice. North American Nursing Diagnosis Association International. NANDA-1 Nursing Diagnoses: Definitions and Classification, Fourth Edition. Philadelphia: Wolters Kluwer Lippincott Williams \& Wilkins; 2003.

4. Yıldız M, Bulut BM. Ölüm kaygısı ile kişilik özellikleri arasındaki ilişkiler. Turkish Studies International Periodical for the Languages, Literature and History of Turkish or Turkic. 2017;12/13:659-676.

5. Nia HS, Lehto RH, Ebadi A, Peyrovi H. Death anxiety among nurses and health care professionals: A review article. Int J Community Based Nurs Midwifery. 2016;4(1):2-10

6. Kızılcı S, Söylemez BA, Uğur Ö, Sezgin D, Küçükgüçlü Ö. iç hastalıkları kliniklerinde çalışan hemşirelerin refakatçiler hakkındaki görüş ve deneyimleri. Anadolu
Hemşirelik ve Sağlık Bilimleri Dergisi. 2013;16(4): 241249.

7. Gürkan A, Babacan GA, Dodak H. Öğrenci hemşirelerin terminal dönem hasta sorunları hakkındaki görüşleri: hemşirelik girişimleri, hasta hakları ve etik sorunlar kapsamında bir inceleme. Maltepe Üniversitesi Hemşirelik Bilim ve Sanatı Dergisi. 2011;4(1):2-12.

8. İnci F, Öz F. Palyatif bakım ve ölüm kaygısı. Psikiyatride Güncel Yaklaşımlar. 2012;4(2):178-187.

9. Özkırış A, Güleç G, Yenilmez Ç, Musmul A, Yanaş M. Hekim tutumları üzerine bir çalışma: ölüm ve ölümcül hastaya yaklaşım. Düşünen Adam Psikiyatri ve Nörolojik Bilimler Dergisi. 2011;24(2):89-100.

10. Işıı Ö, Karaca S. Ölüm yaklaşırken yaşananlar ve söylenebilecekler: bir gözden geçirme. Maltepe Üniversitesi Hemşirelik Bilim ve Sanatı Dergisi. 2009;2(1):82-89.

11. Thiemann P, Quince T, Benson J, Wood D, Barclay S. Medical students' death anxiety: severity and association with psychological health and attitudes to ward palliative care. J Pain Symptom Manage. 2015;50(3):335-342.

12. Benli SS, Yıldırım A. Hemşirelerde yaşam doyumu ve ölüme karşı tutum arasındaki ilişki. Gümüşhane Üniversitesi Sağlık Bilimleri Dergisi. 2017;6(4):167-179.

13. Deffner JM, Bell SK. Nurses' death anxiety, comfort level during communication with patients and families regarding death, and exposure to communication education: a quantitative study. J Nurses Staff Dev. 2005;21(1):19-23.

14. Işık EA. Ölüme karşı tutum ölçeğinin Türk toplumu için geçerlik ve güvenirliği [Yüksek Lisans Tezi]. İzmir: Ege Üniversitesi; 2008.

15. Cooper J, Barnett M. Aspects of caring for dying patients which cause anxiety to first year student nurses. Int J Palliat Nursing. 2005;11(8):423-430.

16. Koç Z, Sağlam Z. Hemşirelik öğrencilerinin yaşam sonu bakım ve ölüm durumuna ilişkin duygu ve görüşlerinin belirlenmesi. C.Ü Hemşirelik Yüksekokulu Dergisi. 2008;12(1):14-17.

17. Çevik B. Hemşirelerin ölüme ve ölmekte olan bireye bakım vermeye ilişkin tutumları ve deneyimleri [Yüksek Lisans Tezi]. Ankara: Başkent Üniversitesi; 2010.

18. Dadfar M, Farid AAA, Lester D, Vahih MKA, Birashk B. Effectiveness of death education program by methods of didactic, experiential, and $8 \mathrm{~A}$ model on the reduction of death distress among nurses. IJMRHS. 2016;5(7):60-71.

19. Ciccarello GP. Strategies to improve end-of-life care in the intensive care unit. Dimens Crit Care Nurs. 2003;22(5):216-222.

20. Templer DI. The construction and validation of death anxiety scale. The Journal of General Psychology. 1970;82(2):165-177.

21. Akca F, Kose A. Adaptation of death anxiety scale (DAS): validity and reliability studies. J Clin Psy. 2008;11(1):7-16. 
22. Dönmez ÇF. Nefroloji hemşirelerinin ve diyaliz hastalarının ölüm kavramına ilişkin görüşleri [Yüksek Lisans Tezi]. Mersin: Mersin Üniversitesi; 2012.

23. Şahin $M$, Demirkıran $F$, Adana F. Hemşirelerde ölüm kaygısı, ölmekte olan hastaya bakım vermeye ilişkin tutumlar ve etkileyen faktörler. Psikiyatri Hemşireliği Dergisi. 2016;7(3):135-141.

24. Hamama-Raz Y, Solomon Z, Ohry A. Fear of personal death among physicians. OMEGA. 2000;41(2):139-149.

25. Madnawat AV, Kachhawa PS. Age, gender, and living circumstances: discriminating older adults on death anxiety. Death Stud. 2007;31(8):763-769.

26. Ayten A. Üniversite öğrencilerinde ölüm kaygısı: Türk ve Ürdünlü öğrenciler üzerine karşılaştırmalı bir araştırma. Din Bilimleri Akademik Araştırma Dergisi. 2009;9(4):85-108.

27. Erdoğdu MY, Özkan M. Farklı dini inanışlardaki bireylerin ölüm kaygıları ile ruhsal belirtiler ve sosyodemografik değişkenler arasındaki ilişkiler. İnönü Üniversitesi Tıp Fakültesi Dergisi. 2007;4(3):171-179.

28. Önsöz SB. Yoğun bakım hemşirelerinin ölüme karşı tutumları ile ruhsal durumları arasındaki ilişkinin incelenmesi [Yüksek Lisans Tezi]. İzmir: Ege Üniversitesi; 2013.

29. İnci F, Öz F. Ölüm eğitiminin hemşirelerin ölüm kaygısı, ölüme ilişkin depresyon ve ölümcül hastaya tutumlarına etkisi. Anadolu Psikiyatri Dergisi. 2009;10(4):253-260.

30. Kurz J, Hayes E. End of life issues action: impact of education. Int J Nurse Educ Scholarsh. 2006;3(18):1-13.

31. McClatchey IS, King S. The impact of death education on fear of death and death anxiety among human services students. OMEGA-Journal of Death and Dying. 2015;71(4):343-361.

32. Lewis C, Reid J, McLernon Z, Ingham R, Traynor M. The impact of a simulated intervention on attitudes of undergraduate nursing and medical students to ward send of life care provision. BMC Palliative Care. 2016;15(1):2-6. 